\title{
The Relationship between Parenting Style and the Emotional Dynamics of Parents, and the Social Interactions of Mentally Retarded Children in Bahagia Foundation Special School in Tasikmalaya
}

\author{
Asep Mulyana1, Tukimin Sansuwito², and Fitria Nurpadila ${ }^{3}$ \\ 1 Lecturer Of The Undergraduate Nursing Study Program, Nursing Faculty, Bhakti Kencana \\ University Tasikmalaya \\ ${ }^{2}$ Lecturer Departement Of Nursing, Lincoln University College Malaysia \\ ORCID: \\ Asep Mulyana: https://orcid.org/0000-0003-4676-9504
}

\section{Abstract}

Corresponding Author:

Asep Mulyana

asep.mulyana@bku.ac.id

Published: 15 March 2021

Publishing services provided by Knowledge E

(c) Asep Mulyana et al. This article is distributed under the terms of the Creative Commons Attribution License, which permits unrestricted use and redistribution provided that the original author and source are credited.

Selection and Peer-review under the responsibility of the IVCN Conference Committee.
Mentally retarded children have below average intelligence. Limited ability makes it difficult to adapt, leading many parents to feel concerned that their children might be unable to interact socially. This study considers the 14 SDLB students at the Bahagia Tasikmalaya Foundation SLB, and aims to determine the relationship between parenting styles and the emotional dynamics of parents on the one hand, with the social interactions of mentally retarded children on the other hand. This research used a quantitative type method with a cross sectional approach, applied to 126 mentally retarded students. The sample used was random sampling with the Slovin formula so that 96 samples were collected with a significance level of 0.05 . The results of this study showed that out of 96 respondents applying democratic parenting 76 people (79.2\%), 13 authoritarian patterns (13.5\%), and 7 premissive (7.2\%). The emotional dynamics of people in positive categories were 89 people or $(92.7 \%)$ and negative categories were 7 people (7.3\%). The social interaction of mentally retarded children in the moderate category was 49 children (51.0\%), the Good category was 33 children (34.4\%), the Less category was 14 children (14.6\%). The conclusion in this study is that there is a significant relationship between parenting styles with mentally retarded children who get a p-value of $0.001<0.005$ and there is a significant relationship between the emotional dynamics of parents and social interactions of mentally retarded children who get $p$-value $0.021<0.005$. Parents need to apply democratic parenting, be able to maintain emotions by generating positive emotional reactions so as to form good social interactions for mentally retarded children.

Keywords: parenting patterns, emotional dynamics and social interactions

\section{Introduction}

Children are a gift from God and are entrusted to their parents. All parents expect S OPEN ACCESS 
child, from several births there are children with disabilities. Mentally retarded children or also known as mentally retarded children, namely children who have intellectuals below average. Limited operational capacity is difficult to adapt [1]. The limitations of mentally retarded children are a must for parents to help take care of themselves [2].

The basis for the obligations of parents in providing parenting as stipulated in the provisions of Law no. 35 of 2014 concerning amendments to Law no. 23 of 2002 concerning child protection, article 14 paragraph 2 , which states that children have the right to care, maintenance, education and protection for the development process of their parents according to their interests and talents [3]. Parenting is an attitude of giving affection in the form of educating, guiding, and giving sanctions to children achieving a better life in accordance with the existing norms in society [4].

Azizah's (2015) research found that 47 respondents $42.6 \%$ had bad social interactions, $40.4 \%$ had poor parenting styles and there was a relationship between parenting styles and social interactions with autistic children [5]. This is in line with Dewi's (2016) research which states that parents who have mild mental retardation children, most of the parenting styles used are authoritarian, namely 25 people $(71.4 \%)$ of 30 parents and 5 respondents applying democratic parenting [2]. Parents who apply authoritarian parenting tend to impose the will of the parents on their children. Children must obey their parents absolutely. Most of them have a mild dependency level of independence.

The impact on children with mental retardation or mental retardation is that children usually get less good parenting from their parents. This results in psychological disorders, low self-esteem and obstacles in carrying out social functions. Children often isolate themselves because they are not expected [6]. However, it is not an easy thing for parents to accept what really happened to their family. Some parents respond to the presence of a child diagnosed with mental retardation, accompanied by feelings of shame about the situation their family is experiencing. When a child is diagnosed with mental retardation, some parents suffer from emotional disorders/stress [7].

Emotional disturbances arise as a result of poor perceptual interpretations so that individual behavior can be influenced by emotional movements in a person. Emotions can unconsciously lead to negative behavior. Silvant Tomkins said that emotions are what motivate life [7]. Emotions can affect the attitudes of parents in carrying out their roles and responsibilities towards children. The presence of children who have limitations, one of which is the mentally retarded child who needs guidance and attention beyond the needs of other children from father and mother. However, if their presence is responded negatively by parents, then the negative emotions that arise from the parents will have an impact on the bad attitudes carried out by mentally retarded children. 
Based on the preliminary results with unstructured interviews through social media WhatsApp conducted by the author to the principal of the Bahagia Foundation SLB school, it was stated that out of 126 mentally retarded students there were several mentally retarded students who had social interactions that had to be guided by their parents, namely students at SDLB grade 1 and 2 , around 14 students mentally disabled. Often children are silent, do not actively speak in class, this can be seen from some parents not taking their children to school as well as by not picking up their children from school because they are busy working, but the children are entrusted to grandmothers, neighbors or even pedicab drivers who have contracted the time to take the children. school.

From the recognition of 4 parents through unstructured interviews with social media WhatsApp, it is stated that emotions often appear suddenly when the child does not follow the directions of the parents, excessive anxiety appears suddenly when they remember that their child has a diagnosis with special needs (mental retardation) felt until now. Based on the description, the authors are interested in conducting research on "The Relationship Of Parenting Style And The Emotional Dynamics Of Parents With Social Interaction Of Mentally Retarded Children In Bahagia Foundation Special School".

\section{Research Methods}

The research design used in this study used a correlational analytic type with a cross sectional approach. In this study, the writer has a desire to know a relationship between the three independent variables and the dependent variable. The variable in question is whether or not there is a relationship between parenting styles and parental dynamics with the social interaction of mentally retarded children at the Bahagia Tasikmalaya Foundation Special School.

The author analyzes the data collected using a research instrument, namely a questionnaire. This questionnaire was used for the variables of parenting styles, emotional dynamics and social interaction variables for mentally retarded children. Researchers will examine whether or not there is a relationship between these three variables, so that mentally retarded children carry out social interactions on the basis of parenting styles that parents provide.

The population of this research is parents who have mental retardation students. There are 126 mentally retarded students at the Bahagia Tasikmalaya Foundation SLB for the 2019/2020 academic year. The 126 students are divided into 3 levels of education, namely the SDLB level totaling 54 students, the SMPLB level totaling 
36 students and the SMALB level totaling 36 students. From a population of 126, the sample used to become respondents used random sampling, namely using the Slovin formula, to find out how many samples were used in a population of 126 students using the Slovin formula, then:

$$
\begin{gathered}
n=\frac{N}{1+N\left(e^{2}\right)} \\
n=\frac{126}{1+126(0,052)} \\
n=\frac{126}{1+126(0,0025)} \\
n=\frac{126}{1,315} \\
n=95,8 \text { rounded up to } 96 \text { samples required. }
\end{gathered}
$$

The inclusion criteria of the sample to be studied are:

1. Parents with children with mental retardation go to the Bahagia Tasikmalaya Foundation SLB

2. Parents with mentally retarded children at the SDLB, SMPLB and $X$ and $X I$ grades of SMA Bahagia Tasikmalaya Foundation

3. Willing to be researched or be a respondent.

The exclusion criteria of the sample to be studied were:

1. Parents who do not have children diagnosed with mental retardation at the Bahagia Tasikmalaya Foundation special school

2. Parents who have mentally retarded students in class XII SMALB Yayasan Bahagia Tasikmalaya

3. Parents who are not willing to be respondents.

This research was carried out in the midst of the current spread of the virus pandemic that is being felt by various countries around the world. In connection with the existence of a social distancing program from the government from the rise of the virus pandemic, the authors get data online via an electronic device, namely a cellphone, where questionnaires are distributed via social media WhatsApp or Google Forms to a 
group of parents of mentally retarded students. This has received permission from the principal and the head of the coordination of parents / guardians of students.

The questionnaire collected 73 responses from respondents who have filled out the questionnaire and have been distributed via social media WhatsApp or Google Forms, while 23 respondents were constrained in filling out the online questionnaire so that the authors conducted a field survey with home visits to distribute the questionnaire directly by implementing health protocols according to the protocol. covid-19 recommended by the government.

In this study the authors conducted an unstructured interview with the principal of the Bahagia Tasikmalaya Foundation SLB through a communication tool in the form of a cellphone, because it was not possible to conduct face-to-face interviews or meetings. This is emphasized in the government lock down or social distancing program in the midst of a viral pandemic outbreak.

\section{Results}

The research results describe the demographic data of respondents, the univariate analysis describes the application of the type of parenting, the emotional picture of the parents and the description of the social interaction of mentally retarded children.

\subsection{Demographic Data}

Based on table 1 showed that most of the respondents have mentally retarded children aged 14-18 years as many as 45 children (46.9\%). Most of the children with mental retardation were male as many as 56 children (58.3\%), most of the mentally retarded children in the Bahagia Tasikmalaya Foundation SLB are Muslim as many as 95 children (99.0\%), most of the parents' education is at high school level as many as 43 people (44.8\%).

\subsection{Univariate Analysis}

Based on table 1 showed that most of the parents apply the type of democratic parenting as many as 76 people (79.2\%), most of the parents show positive emotionality as many as 89 people (92.7\%), that the social interactions of mentally retarded children in SLB Yayasan Bahagia Tasikmalaya are mostly in quite as much 49 children (51.0\%). 
TABLE 1: Distribution of Respondents Characteristics Based of Mentally Retarded Children in Bahagia Foundation Special School Tasikmalaya

\begin{tabular}{|c|c|c|c|}
\hline & & Frequency & Percentage \\
\hline \multirow[t]{5}{*}{ Age } & 6-10 tahun & 19 & $19.8 \%$ \\
\hline & 11-13 tahun & 22 & $22.9 \%$ \\
\hline & 14-18 tahun & 45 & $46.9 \%$ \\
\hline & 19-24 tahun & 10 & $10.4 \%$ \\
\hline & Amount & 96 & $100 \%$ \\
\hline \multirow[t]{3}{*}{ Gender } & Male & 56 & $58.3 \%$ \\
\hline & Female & 40 & $41.7 \%$ \\
\hline & Amount & 96 & $100 \%$ \\
\hline \multirow[t]{3}{*}{ Religion } & Islam & 95 & $99.0 \%$ \\
\hline & Christian & 1 & $1.0 \%$ \\
\hline & Amount & 96 & $100 \%$ \\
\hline \multirow[t]{7}{*}{ Education } & SD & 18 & $18.8 \%$ \\
\hline & SMP & 22 & $22.9 \%$ \\
\hline & SMA & 43 & $44.8 \%$ \\
\hline & D2 & 1 & $1.0 \%$ \\
\hline & D3 & 2 & $2.1 \%$ \\
\hline & $\mathrm{S} 1$ & 10 & $10.4 \%$ \\
\hline & Amount & 96 & $100 \%$ \\
\hline
\end{tabular}

TABLE 2: Distribution of Characteristics of Parent Respondents with Children with Disabilities in the Bahagia Tasikmalaya Foundation Special School

\begin{tabular}{|l|l|c|c|}
\hline & & Frequency & Percentage \\
\hline & Authoritarian & 13 & $13.5 \%$ \\
\hline & Democratic & 76 & $79.2 \%$ \\
\hline & Permissive & 7 & $7.2 \%$ \\
\hline Emotional Dynamics & Amount & 96 & $100 \%$ \\
\hline \multirow{3}{*}{ Social Interaction } & Positive & 89 & $92.7 \%$ \\
\hline & Negative & 7 & $7.3 \%$ \\
\hline & Amount & 96 & $100 \%$ \\
\hline & Good & 33 & $34.4 \%$ \\
\hline & Enough & 49 & $51.0 \%$ \\
\hline & Less & 14 & $14.6 \%$ \\
\hline
\end{tabular}

Based on table 3 showed that the percentage of parent who applies authoritarian parenting gets the social interaction results of mentally retarded children in the enough category of 7 children.

Based on table 4 showed that the percentage of parents who apply democratic parenting is in the moderate category as many as 39 children. 
TABLE 3: Distribution of Respondents Characteristics Based on the Application of Authoritarian Parenting with the Social Interactions of Mentally Retarded Children in Bahagia Foundation Special School Tasikmalaya

Social Interaction
Good
Enough
Less

Amount

\begin{tabular}{|c|}
\hline Non authoritarian \\
\hline 28 \\
\hline 42 \\
13 \\
83 \\
\hline
\end{tabular}

83

\begin{tabular}{c} 
Authoritarian \\
\hline 5 \\
7 \\
1 \\
13 \\
\hline
\end{tabular}

\begin{tabular}{|c|}
\hline Total \\
\hline 33 \\
\hline 49 \\
\hline 14 \\
\hline 96 \\
\hline
\end{tabular}

TABLE 4: Distribution of Respondents Characteristics Based on the Application of Democratic Parenting with the Social Interactions of Mentally Retarded Children in Bahagia Foundation Special School Tasikmalaya

Social Interaction
Good
Enough
Less
Amount

\begin{tabular}{|c|}
\hline Non-Democratic \\
\hline 7 \\
10 \\
3 \\
\hline 20 \\
\hline
\end{tabular}

\begin{tabular}{|c|}
\hline Democratic \\
\hline 26 \\
\hline 39 \\
\hline 11 \\
\hline 76 \\
\hline
\end{tabular}

\begin{tabular}{|c|}
\hline Total \\
\hline 33 \\
\hline 49 \\
\hline 14 \\
\hline 96 \\
\hline
\end{tabular}

TABLE 5: Distribution of Respondents Characteristics Based on the Application of permissive Parenting with the Social Interactions of Mentally Retarded Children in Bahagia Foundation Special School Tasikmalaya

Social Interaction
Good
Enough
Less
Amount

\begin{tabular}{|c|}
\hline Non Permissive \\
\hline 32 \\
\hline 43 \\
14 \\
\hline $\mathbf{8 9}$ \\
\hline
\end{tabular}

\begin{tabular}{|c|}
\hline Permissive \\
\hline 1 \\
\hline 6 \\
0 \\
\hline 7 \\
\hline
\end{tabular}

\begin{tabular}{|c|}
\hline Total \\
\hline 33 \\
\hline 49 \\
14 \\
\hline 96 \\
\hline
\end{tabular}

Based on table 5 showed that the percentage of parents who apply premissive parenting gets the social interaction results of mentally retarded children in enough categories as many as 6 children.

TABLE 6: Distribution of Respondents Characteristics Based on the Emotions of the Emotional Dynamics of the Parents with the Social Interactions of Mentally Retarded Children in Bahagia Foundation Special School Tasikmalaya

Social Interaction
Good
Enough
Less
Amount

\begin{tabular}{|c|}
\hline Negative \\
1 \\
6 \\
0 \\
7 \\
\hline
\end{tabular}

\begin{tabular}{|c|}
\hline Positive \\
\hline 32 \\
\hline 43 \\
14 \\
\hline 89 \\
\hline
\end{tabular}

\begin{tabular}{|c|}
\hline Total \\
\hline 33 \\
\hline 49 \\
14 \\
\hline 96 \\
\hline
\end{tabular}

Based on table 6 showed the percentage of the application of the emotional dynamics of parents with the social interaction of mentally retarded children at the SLB Bahagia Tasikmalaya Foundation, giving rise to positive emotional dynamics reactions getting the results of social interactions in sufficient categories as many as 43 children. 


\subsection{Bivariate Analysis}

TABLE 7: The Relationship of Parenting Style with the Social Interactions of Mentally Retarded Children in Bahagia Foundation Special School Tasikmalaya

\begin{tabular}{|c|c|c|c|c|c|c|}
\hline \multicolumn{6}{|c|}{ Parenting Style } & \multirow[t]{2}{*}{$P$-Value } \\
\hline $\begin{array}{l}\text { Social } \\
\text { Interactions }\end{array}$ & Authoritarian & Democratic & Permissive & Total & Percentage & \\
\hline Good & 5 & 26 & 1 & 33 & & 0.001 \\
\hline Enough & 7 & 39 & 6 & 49 & & \\
\hline Less & 1 & 11 & 0 & 14 & & \\
\hline Amount & 13 & 76 & 7 & 96 & $100 \%$ & \\
\hline
\end{tabular}

Based on table 7 after the Spearman rank statistical test was carried out, the p-value $=0.001$ was smaller than $\alpha<0.05$, which means that $\mathrm{HO}$ was rejected. $\mathrm{HO}$ is rejected that there is a significant relationship between parenting styles and social interactions of children with mental retardation in SLB Yayasan Bahagia Tasikmalaya.

TABLE 8: The Relationship Between the Emotional Dynamics of Parents and the Social Interactions of Mentally Retarded Children in Bahagia Foundation Special School Tasikmalaya

\begin{tabular}{l|c|c|c|c|c|}
\multicolumn{5}{|c|}{ Parenting Style } & P-Value \\
\begin{tabular}{l|c|c|c|c|c|} 
Social \\
Interactions
\end{tabular} & Negative & Positive & Total & Percentage & \\
\hline Good & 1 & 32 & 33 & & 0.021 \\
\hline Enough & 6 & 43 & 49 & & \\
\hline Less & 0 & 14 & 14 & & \\
\hline Amount & $\mathbf{7}$ & $\mathbf{8 9}$ & $\mathbf{9 6}$ & $\mathbf{1 0 0 \%}$ & \\
\hline
\end{tabular}

Based on table 8 after the Spearman rank statistical test was carried out on 96 respondents, the p-value $=0.021$ was smaller than $\alpha<0.05$, which means that $\mathrm{HO}$ was rejected. $\mathrm{HO}$ rejected means that there is a significant relationship between the Emotional Dynamics of Parents and the Social Interaction of Children with Disabilities in SLB Yayasan Bahagia Tasikmalaya.

\section{Discussion}

\subsection{Demographic Data}

Table 1 Distribution of Characteristics of Respondents Based on the Age of Mentally Retarded Children At the Bahagia Foundation Special School Tasikmalaya shows that most of the respondents have 45 children with mental retardation aged 14-18 years (46.9\%) and a small proportion are in the 19-24 year age category as many as 10 children 
(10.4\%). From SDLB to SMALB level. The age factor was related to the social interactions of children with autism, namely the higher the age, the better their social interactions. Thus it is the same as with social interactions in mentally retarded children, the higher the age, the better the social interactions of mentally retarded children. Apart from age, it is closely related to religion and parental education [8].

Gender Characteristics of Mentally Retarded Children in Bahagia Foundation Special School Tasikmalaya shows that most of them are male, as many as 56 children or (58.3\%). The results show that the majority of children with disabilities are male. Male gender is dominant in this entire sample. This research is supported by Suharni et al. (2016) researched the Parenting Style of Autistic Children Social Interaction at Insan Mandiri Foundation Pisang Kipas Street No 34A Jati Mulyo Village Malang that children who experience autism are mostly male as many as 9 out of 15 respondents [9]. Twistiandayani \& Umah (2017) from their research, found that the gender factor has no relationship with children's social interaction. This reinforces the theory that children with male gender are more found with autism or disabilities that are influenced by sex hormones. Male have the hormone testosterone which inhibits the performance of RORA, a gene that regulates brain function (Retionic Acid-Related Orphan ReseptorAlpha) [8].

\subsection{Univariate Analysis}

Based on Table 2, parenting characteristics given by parents to mentally retarded children in Bahagia Foundation Special School Tasikmalaya shows the results of parents providing parenting in the democracy category as many as 76 people or $(79.2 \%)$, as many as 13 or (13.5\%) parents apply authoritarian parenting and as many as 7 or (7.2\%) parents apply permissive parenting. This means that this study found the results of most parents applying democratic parenting. This research was supported by Suharni et al (2016) get the most of the democratic Parenting style as many as 15 people or (100\%) [9]. This is in line with research Bahri (2014) explains that parenting is a behavior that is given to children that is consistent or permanent.

Children will feel this pattern of behavior either positive or negative in interacting, communicating during parenting activities. The parenting given by each parent is different, whether it is coercive (Authoritarian), free under observation (Democratic) or even free as freely as possible to the child without any reprimand (permissive) [10]. Authoritarian parenting has a character that imposes the will of the parents absolutely on the child without any resistance. The democratic parenting given by parents to children 
is that parents always respect and pay attention to children's freedom in monitoring and guidance. Taking into account the child's opinion on the reasons taken in a decision. Meanwhile, permissive parenting is a type of parenting that does not strictly enforce the rules and tends to ignore and forgive problematic behavior [11].

Based on Table 3 emotional dynamic characteristics given by parents to mentally retarded children in Bahagia Foundation Special School Tasikmalaya shows the percentage of each type of emotional dynamics of parents to mentally retarded children. Most of the emotional dynamics of parents were described in the positive category as many as 89 people or (92.7\%) and a small part of the emotional dynamics described by parents in the negative category were 7 people or (7.3\%). This is in line with the research conducted by Qomamadani (2017) the results of his research were carried out on three parents who have autistic children, where they generate negative emotional reactions when the child is suspected of having autism, over time they become positive emotional reactions but often feel negative reactions appear immediately in time [7] Dynamics can be said to be the movement of emotions that appear in a changing manner in a person. This event becomes the stimulus for the emergence of a further incident [12]. Dynamics means that there is a simple relationship between groups of interactions that leads to positive or negative behavior [13].

Based on Table 3 respondent characteristics based on the social interactions of mentally retarded children in Bahagia Foundation Special School Tasikmalaya shows that the percentage of each social interaction of mentally retarded children mostly gives an overview in the enough category as many as 49 children or (51.0\%). This research was supported by Suharni et al (2016) get the results of social interaction of respondents as many as 12 people. The results obtained $\rho$ - value $=0,000<\alpha(0,05)$ [9]. Social interaction is a social relationship that affects each other between individuals, groups and communities [14].

\subsection{Bivariate Analysis}

\subsubsection{The Relationship between Parenting Style and the Social Interac- tion of Mentally Retarded Children in Bahagia Foundation Special School Tasikmalaya}

Based on Table 7 The Relationship Between Parenting Styles with the Social Interactions of Mentally Retarded Children has the results that have been carried out by the spearman rank statistical test of the three types of parenting, namely authoritarian parenting, democratic parenting and permissive parenting to 96 respondents, obtained 
$\mathrm{p}$-value $=0.001$ is smaller than $\alpha<0.05$, which means that $\mathrm{HO}$ is rejected. $\mathrm{HO}$ is rejected which means that there is a significant relationship between the types of Parenting Style and Social Interactions of Mentally Retarded Children in Bahagia Foundation Special School Tasikmalaya.

This research is in line with research conducted by Suharni et al (2016) the results showed that all (100\%) of the respondents applied democratic parenting and there were only 12 respondents' social interaction. The result is $\rho$ value $=0.000<\alpha(0.05)$, so that $\mathrm{HO}$ is rejected, it can be concluded that there is a relationship between parenting and social interaction in children with autism [9]. This is in line with Azizah (2015) research which explains that there is parenting relationship with parents autistic child social interactions [5]. Bahari (2014) explains that children will feel this pattern of behavior both positive and negative in interacting, communicating during parenting activities. In this case the theory strengthens the results of this study that the parenting style of parents with social interactions of mentally retarded children has a mutually sustainable bond or relationship [10].

Researchers assume that the parenting style that children perceive as a good parenting style is democratic parenting which describes the openness of communication between children and parents so that it creates good children's social interaction. Children will feel happy if their opinions are respected and embraced by parents so that a positive emotional reaction appears in the hearts of parents with gratitude to see their children communicate actively. Likewise, if the authoritarian parenting style is enforced by force, the child will feel pressured by the situation between the child and the parents, if the child violates, it will cause annoyance that appears as a feeling experienced by the parents so that the relationship between parenting forces that creates negative emotions, the child will also cause less interaction due to stressful situations Likewise with the application of permissive parenting where parents are indifferent to their children, the children will at will bring out feedback that the children likes too.

\subsubsection{The Relationship between Parents Emotional Dynamics and Social Interaction of Mentally Retarded Children in Bahagia Foun- dation Special School Tasikmalaya}

Based on Table 8 the relationship between the emotional dynamics of parents and the social interaction of mentally retardated children has results that have been carried out by the spearman rank statistical test on 96 respondents obtained $p$-value $=0.021$ 
is smaller than $\alpha<0.05$, which means that $\mathrm{HO}$ is rejected. $\mathrm{HO}$ rejected means that there is a significant relationship between the Emotional Dynamics of Parents and the Social Interaction of Mentally Retardated Children in Bahagia Foundation Special School Tasikmalaya. Parental emotional dynamics means emotional movement or emotional stability that parents feel as a result of an event or response to something that has happened. Every parent has different emotional reactions when dealing with mentally retarded children so that they are able or not to realize their emotions or parents are able or not to regulate emotions under stress which is called emotion regulation. This is supported by Gross (2007) theory concerning aspects of emotional regulation, namely able to regulate positive emotions as well as negative emotions, able to be aware of emotions, control emotions consciously and automatically, able to control the pressure resulting from the problems at hand [15]. Based on the overall results of this study, it is explained that there is a relationship between the Emotional Dynamics of Parents and the Social Interaction of Children with Disabilities in SLB Yayasan Bahagia Tasikmalaya.

The author reveals that in addition to the type of parenting that parents apply in educating their children, of course there are many more factors that influence the social interactions of mentally retarded children. The limitation of mentally retarded children in interacting is that parents must pay attention to how to communicate, because mentally retarded children have limitations in language. Factors affecting the social interactions of mentally retarded children that parents must know are imitation, Imitation or the act of imitating another person. For example, speaking style, behavior, tradition and habits, mindset. In this case, mentally retarded children try to find new ways to communicate to interact. In addition, the role of parents in providing support to mentally retarded children is expected to be able to increase the social interaction of mentally retarded children. In this case, cooperation between parents and children is needed because cooperation is one of the main forms of social interaction. And parents are able to maintain direct communication with children as an effort to provide a good healing process for mentally retarded children.

Less attention given from parents to children in carrying out interactions will make it difficult for children to interact with both parents and peers. There are things that can increase the social interaction of children with autism, namely the need to interact with peers in carrying out joint activities that provide fun for mentally retarded children as the start of a good social interaction [9] 


\section{Conclusion}

The social interactions of mentally retarded children mostly provide an overview in the sufficient category as many as 49 children or (51.0\%), only a portion of the social interactions of mentally retarded children in the Good category were 33 children or (34.4\%), and a small proportion of the social interactions of mentally retarded children are in the less category as many as 14 children or (14.6\%).

After doing statistical tests rank spearman obtained $p$-value $=0.001$ is smaller than $\alpha<0.05$, which means that $\mathrm{HO}$ is rejected. $\mathrm{HO}$ is rejected that there is a significant relationship between Parenting Styles and Social Interactions of Mentally Retarded Children in Bahagia Foundation Special School Tasikmalaya. While the p-value $=0.021$ is smaller than $\alpha<0.05$, which means that $\mathrm{HO}$ is rejected. $\mathrm{HO}$ rejected means that there is a significant relationship between the Emotional Dynamics of Parents and the Social Interaction of Mentally Retarded Children in Bahagia Foundation Special School Tasikmalaya.

\section{References}

[1] ELDIA MAY YORA, E. M. Y. (2019). pengaruh terapi bermain lego (block) terhadap kemampuan beradaptasi sosial pada anak penyandang tunagrahita di sekolah luar biasa al-azra'iyah tabek panjang kec. Payakumbuh tahun 2019 (Doctoral dissertation, stikes perintis padang).

[2] Dewi, V. K. (2017). Hubungan pola Asuh Orang Tua Dengan Tingkat Kemandirian Anak Retardasi Mental Ringan di SDLB YPLB Banjarmasin. An-Nadaa: Jurnal Kesehatan Masyarakat, vol. 4, issue 1, pp. 21-5.

[3] Rahayu, E. (2019). Hubungan Pola Asuh Orang Tua Dengan Tingkat Kemandirian Anak Autis Di Wilayah Kota Tasikmalaya Tahun 2019. (Eneng Rahayu, S.Kep Universitas Bhakti Kencana Tasikmalaya, 2019).

[4] Rohayati, D. A. (2017). Hubungan Pola Asuh Orangtua Dengan Perilaku Moral Tidak Baik Siswa Smp Negeri 14 Muaro Jambi (Doctoral dissertation, Universitas Jambi).

[5] FATIAH AZIZAH, F. A. (2015). Hubungan pola asuh orang tua dengan interaksi sosial anak autis di sekolah luar biasa al ikhlas garegeh kota Bukittinggi tahun 2015 (Doctoral dissertation, STIKes PERINTIS PADANG).

[6] Duri, D. R., Yati, D., \& Ambarketawang, G. (2018). GAMBARAN POLA ASUH ORANG TUA PADA ANAK RETARDASI MENTAL (INTELECTUAL DISABILITY) DI SLB BAKTI SIWI SLEMAN. Jurnal Kesehatan Saelmakers PERDANA, 1(2), 18. 
[7] Ruhila, H. Q. and Hm, Sa-G. (2017). Dinamika Emosi Orang Tua Yang Memiliki Anak Terdiagnosis Autis Studi Kasus di SD Al-Firdaus Surakarta. (IAIN Surakarta, 2017).

[8] Twistiandayani, R. and Umah, K. (2017). Faktor-Faktor Yang Mempengaruhi Interaksi Sosial Pada Anak Autis. Prosiding SNaPP: Kesehatan (Kedokteran, Kebidanan, Keperawatan, Farmasi, Psikologi), vol, 3, issue 1, pp. 23-30.

[9] Suharni, S., Eka, N. L. P. and Maemunah, N. (2016). Hubungan Pola Asuh Orang Tua Terhadap Interaksi Sosial Pada Anak Autis di Yayasan Insan Mandiri Jl. Pisang Kipas No. 34A Kelurahan Jatimulyo Malang. Nursing News: Jurnal IImiah Keperawatan, vol. 1 , issue 1

[10] Djamarah, S. B. (2014). Pola Asuh Orang Tua Dan Komunikasi Dalam Keluarga. Jakarta: Rineka Cipta.

[11] Setiono, K. (2011). Psikologi Keluarga. Bandung: PT Alumni.

[12] AT, N., \& FADHILAH, M. (2014). Dinamika emosi pada remaja dari keluarga yang bercerai (Doctoral dissertation, Universitas Muhammadiyah Gresik).

[13] Rohmah, F., \& Harahap, L. (2018). Dinamika Emosi Pada Pasangan Pernikahan Kawin Hamil di Kelurahan Pucang Sawit Kecamatan Jebres Kota Surakarta.

[14] Mubin Mz, S. (2015). INTERAKSI SOSIAL WANITA SINGLE PARENT (Doctoral dissertation, UIN Sunan Ampel).

[15] Gross, J. J. (2014). Emotion regulation: Conceptual and empirical foundations. APA Psyclnfo: Washington, DC. 